PART 1

Theorizing Violence in an Extractive Age 
$\Longrightarrow$ Taylor \& Francis

Taylor \& Francis Group

http://taylorandfrancis.com 


\title{
1
}

\section{EXTRACTION AND EXTRACTIVISMS}

\section{Definitions and Concepts}

\author{
Francesco Durante, Markus Kröger, and William LaFleur
}

The first section is translated from the Portuguese, from an interview with Aldira Munduruku conducted by Markus Kröger in November 2019 on the shores of Tapajós river in a village inhabited by the Munduruku people, south of Itaituba in the Amazon Basin, Pará, Brazil:

MARKUS: From the time you got here, to this day, has life changed? For example, are there more fish, or fewer fish, more trouble, or less trouble, what was it like before and what is it like now?

ALDIRA: Every year things change, you know? So the climate is also changing, the sun comes very hot, and the river is also not filling correctly, from time to time it fills, then dries, fills, dries...so, every year it's been changing. Also, the lack of fish. At times there is not much fish. Game too, there is no more game behind the village. Because, you know, there are many access roads [illegally built inside the Amazon rainforest areas of the Munduruku people]. We saw them and the warriors got lost because of so many access roads that the Pariuás [non-indigenous people] are making, right, the acai palm-heart cutters, the loggers. So, my husband goes often to hunt on this side, you know, and almost every time he brings nothing. This is the way we live, and then comes the hunger. Then, fish not so many, right? Fishing, every time he goes fishing, he brings fish, even if they are small.

MARKUS: How do you see your children's future, do you think they're going to live here, or do you think they're going to have to move from here, how are they going to be when they're grown?

ALDIRA: I still have hopes that our area will be demarcated. Bolsonaro's government is always bringing bad projects to us, death projects as we call them. But we're going to face him until... until death. Until we get the demarcation. And my hope is that my children will be happy with the demarcation, right? And we're going to be feeling at peace. And I have hopes that my children will always live here. 


\section{Introduction}

Extractivism characterizes the modern era. We define extractivism in this publication as a particular way of thinking and the properties and practices organized towards the goal of maximizing benefit through extraction, which brings in its wake violence and destruction. Extractivism plays out particularly brutally at resource frontiers, invisible to the majority of the distant users of the commodities appropriated under this frontierlogic (Moore, 2015). Yet globalization has made the effects—physical, social, and mental - of the ever-intensifying extractivisms more visible, as they increase in scale and scope to maintain the global rush into modernity (Kröger, 2015). Ignorance about the tolls of extractivism and an increase in hyper-extractive activity is no longer an excuse. Nonetheless, the violence played out against humans and other living beings, as well as against lived environments on the multiple frontiers of extractivisms need to be further scrutinized (Acosta, 2013; Taylor, 2015; Gudynas, 2015; McNeish, 2018; de la Cadena and Blaser, 2018; Svampa, 2019; Kröger and Nygren, 2020).

The modern era has seen a rise in the scope and scale of extractivist violence. A major driving factor has been the global expansion of extractive activities by traditional powers and rising economic powers, such as China (see Li and Shapiro in this volume). However, technological advances have played a significant role in transforming ontologies, practices, and spiritual, reciprocal, or sacredness-based relations with the environment and the planet (Merchant, 1983). In addition, these technological advances support an increased volume of extraction (Gudynas, 2015; Dunlap and Jakobsen, 2020) and allow a window into the extractivist activities taking place. In previous eras these activities might have remained unseen, playing out at frontiers in marginalized spaces (Peluso and Watts, 2001; Arboleda, 2020).

However, the logic of extractivism is still firmly in place. The violent logic of taking resources - without reciprocity, without stewardship - has gained traction in the past two decades, despite an increase in on-the-ground resistance and some localized regulatory attempts to hamper its operations and impacts (Jalbert et al., 2017; Willow, 2018; Kröger, 2013; 2020a). In addition to the evident push for natural resource extraction, the underlying logic of extractivism is increasingly revealed to be a fundamental driving force of capitalism-as well as of other modern world-systems (Szelényi and Mihályi, 2020). In fact, the extractivist logic, operating through depletion, has been in operation for thousands of years (e.g. over-logging, deforestation, etc.), as empires have been built and capital amassed for wealthy families, enterprises, and colonizing powers (Frank and Gills, 1993; Perlin, 2005). While empires have been resisted by local communities for thousands of years, less has been written about this because history tends to be written by the winners, the established "civilizations," and states. This kind of resistance based on rooted dwelling and anti-state attitudes is still visible, as e.g. Scott (2017), de la Cadena and Blaser (2018), and Kröger (2020a) have elucidated ethnographically. As non-modernist framings stemming from these communities have 
proliferated (Kröger, 2013), sectors of the global economic system that have not historically been directly associated with the concept of extractivism, such as the financial and digital sectors, are now increasingly being understood as "extractive," "colonial," and a feature of contemporary capitalism(s) (Thatcher et al., 2016; Gago and Mezzadra, 2017; Mezzadra and Neilson, 2017; Couldry and Meijas, 2019; Sadowski, 2019; Dunlap and Jakobsen, 2020). These new arenas of extractivism are multi-faceted and change rapidly as the technological capability and creativity for their myriad uses (and abuses) continues to evolve, as we see in chapters in this volume by Chagnon et al., Li and Shapiro, and Nicholson.

In this chapter, we explore the etymological evolution of the concept of extractivism and the developmental trajectory that has served to inform the underlying and overarching extractivist logic. This could be described as the extractivist mindset, or ontology, which has its particular expressions, practices, and understandings in different extractive sectors, which have become global (global extractivisms). As a result, we aim to cast light on the ontological underpinnings that inform extractivist logic, or as we refer to it here, an extractivist "onto-logic" that underwrites the machinations of much globalized economic activity, from natural resources to the digital and data infrastructures on which the world is increasingly dependent. The final section brings the paper full circle, linking the opening vignette with a discussion on resistance, including the way that this has been approached through the concept of extrACTIVISMS as developed by Willow (2018) and, in this volume, by Wapner and by Richardson and McNeish, highlighting resistances to the lived material consequences of this hegemonic ontologic. We conclude that extractivist logics are inextricably bound up with colonialism, capitalism, and other configurations of modernity, and that distinct modes of violence are associated with different extractivist spheres.

\section{Definitions of Extractivism and Extraction}

The term extractivism derives from the Latin American concept of "extractivismo," which originally emerged in the 1970s to describe developments in the mining and oil export sectors (Gudynas, 2018). The word originates from the Latin verb "extrahĕre" which is a combination of "ex-" meaning "from" and "trahĕre" meaning "draw." Thus, extrahĕre quite directly means to 'draw from' (Willow, 2018). One of the most widely used definitions of extractivism in the academic literature relates extractivism solely to natural resources, "appropriation of natural resources in large volumes and/or high intensity, where half or more are exported as raw materials, without industrial processing or with limited processing" (Gudynas, 2018, p. 62).

Extractivism is often categorized as a feature, imperative, or characteristic. For example, it is described as "a mode" (Acosta, 2013, p. 62), or "a particular mode of capitalist accumulation" (Teràn Mantovani, 2016, p. 257: "un particular modo de acumulación capitalista"), a "structural feature of capitalism as a world economy" (Machado Aràoz, 2013, p. 131: "un rasgo estructural del capitalismo como economíamundo"), and as the "imperative driving the global capitalist economy" (Dunlap 
and Jakobsen, 2020, p. 6). Furthermore, in its version of neo-extractivism, the concept is labelled as "a way of appropriating nature" (Svampa, 2019, p. 6) and an “economic...(and) development model”" (Brand et al., 2016, pp. 133, 131) or solely as a "development model" (Svampa, 2019, p. 6).

The concept of extractivism is related to and builds on a long prior tradition of political ecology and political economy critical of resource extraction, especially in Latin America, and focused particularly on excessive and highly conflictive mining expansion in the Andes region (see Bebbington and Bury, 2013). The terms extraction and extractivism stand in an ambiguous yet symbiotic relation (Kröger, 2020b). There are particular literatures for the global analysis of different extractive sectors, as well as key actors and dynamics, such as the roles of social movements, states, and corporations (Kröger, 2020c). Specific literatures on agrarian or agro-extractivism further specify the terms and offer analytical tools to use the concepts for analyzing recent transformations, especially in the Latin American countryside, through political economy and political ecology (McKay, 2017; Alonso-Fradejas, 2018). Meanwhile, forestry extractivism in the form of monoculture tree plantations is a constantly growing trend, pursued under the umbrella label of a so-called bioeconomy (Kröger, 2013; 2016), with carbon sequestration and other claims hiding the actual circumstances of rising pollution and deaths caused by such extractivist expansions (Ehrnström-Fuentes and Kröger, 2018; Kröger and Ehrnström-Fuentes, 2020).

More recently, authors from different disciplines with a wide-spanning scope of foci have tried to comprehend the essence of extractivism in order to expand its analytical use to other applications, such as in the financial sector (Gago and Mezzadra, 2017; Mezzadra and Neilson, 2017) and digital environments (Sadowski, 2019). In the case of the digital environment, data extraction consists of information being "taken without meaningful consent and fair compensation" (Sadowski, 2019, p. 7). As for extractivism, Gago and Mezzadra (2017) follow the definition of Acosta (2015), "extraction of huge volumes of natural resources, which are not at all or only very partially processed and are mainly for export according to the demand of central countries" (translated in Gago and Mezzadra, 2017, p. 576). Insights can be drawn from these theories on extraction to delve into the meaning of extractivism.

To be able to deconstruct the word "extraction," we make a quick exploration of the verb "extract" and its current use in American and British English dictionaries. The Merriam-Webster's Dictionary ${ }^{1}$ provides the following pertinent definitions of the transitive verb "extract": 1 a: to draw forth; 1 b: to pull or take out forcibly, 1 c: to obtain by much effort from someone unwilling. These definitions ascribe to the verb the qualities of strength and effort, especially addressed against a non-cooperative counterpart. Therefore, one can discern here the violent nature of extraction. The former feature is described by Gago and Mezzadra regarding finance as "an accumulation of drawing rights on the wealth to be produced in future" (Gago and Mezzadra, 2017, p. 583), as well as extraction as "forced removal" (Mezzadra and Neilson, 2017, p. 188). Finally, the aspect of unwillingness is found in Sadowski concerning data being "taken without meaningful consent" (2019, p. 7). 
A second set of definitions reveals an additional interesting feature: 2 a: to withdraw (something, such as a juice or a constituent element) by physical or chemical process, $2 \mathrm{~b}$ : to treat with a solvent so as to remove a soluble substance, 3: to separate (a metal) from an ore. The Oxford English Dictionary ${ }^{2}$ reports the same meanings, adding an extra nuance in its definition 2 a: to take from something of which the thing taken was a part.

These last definitions describe actions that as practiced on the ground often result in irreversible transformations that radically change the target of extraction, such as the landscape and the environment and often also the socio-economic and ecological relations between and within populations and landscapes. In other words, such transformation results in major modifications, as through the loss of lives and spaces to live, which in turn affects the inhabitants of a given territory. Mezzadra and Neilson describe this element as "processes that cut through patterns of human cooperation and social activity" (2017, p. 194). Ye et al. (2020) provide a deeper analysis of capital accumulation, value creation, and the political economic and agrarian dimensions of extractivism, noting that typically these are actions "where value generation is necessarily temporary and generally followed by barrenness and an inability to sustainably reproduce livelihoods in the affected habitat" (p. 155).

Concerning the word extractivism, the attention to the noun suffix "-ism" sheds light on the relation between extraction and extractivism, conferring pre-eminence to the former, yet providing foundations and clarifying the latter. Looking to the Latin languages - as the concept of extractivismo was developed in a Spanish-speaking context - we can find more nuance in the definition compared to the English definition of "-ism." The Spanish dictionary ${ }^{3}$ reveals that "-ismo" primarily gives the meaning of a doctrine, system, school, or movement. Then it provides attitude, tendency, and quality. In the Dictionary of Physical Sciences in Italian ${ }^{4}$ (which sometimes preserves more original meaning in words derived from Latin), "-ismo" denotes abstract concepts such as a way of thinking or properties of a thing, or a bundle of things organized towards a certain goal (as a mechanism). Based on this definition, in contrast to "extraction," we see that the concept of "extractivism" should be used to denote, in an abstract way, a particular way of thinking and the properties and practices organized towards the goal of maximizing benefit through extraction. This would allow for wider comparisons through "extractivism" as a heuristic device and an underlying logic, allowing for comparability across quite similar instances of the same process between different contexts, while retaining the possibility for specific instances to be explored in detail.

The specific act of extraction, then, is different from extractivism, which can be understood as a constellation of logics or drivers, but the first is a prerequisite to talk about the second. The scoping of dictionaries above allows one to see the different nuances of extractivism, as either a feature of something (a political regime), a doctrine, a theory (e.g. economic or social), an attitude, or a disposition, such as in ontology. Extractivism also denotes being organized towards a goal, these goals varying from development to profit, and even to changes in ideology or mindsets. 
To conclude this etymological excursus, it is worth noting that the concepts of extraction and extractivism, so far exposed, present also their respective homonyms yet antithetical notions. These are extrACTION (Jalbert et al., 2017) and extrACTIVISM (Willow, 2018), denoting in toto active rejection of and resistance to the extractivist logic. As part of the new wave of environmental movements, this activism incarnates environmental justice by an in loco resistance and contestation against large-scale extractive activities, standing firmly against the predominant extractivist mindset (Wapner, this volume). In sum, the definitions and the etymology of the term extractivism shed light on the intrinsically violent nature of extraction, providing us with two foci of inquiry. The aspect of strength opens up the realm of power relations, while the unwillingness of the affected subjects introduces issues of freedom. If these two aspects are taken together, they can effectively launch extractivism into new spheres of analysis.

\section{Universalizing Exploitation as Natural}

In an attempt to conceptualize the violence of modern extractivist practices, it is necessary to trace the seeds of this onto-logic as it has operated through the centuries and forms the functional core of the modern world-system and world-ecology (see Moore, 2015). What is now referred to as extractivism did not spontaneously emerge in European colonial times, nor does it characterize only one economic system (capitalism), but indeed permeates other modern iterations - socialism and its variants included (Gudynas, 2018). Scholars have shown that modern extractivist practices began to take root, or at least gather significant momentum, around 500 years ago (Wallerstein, 1974; Mintz, 1986; Escobar, 1995; Acosta, 2013; Gudynas, 2015; Moore, 2015; Willow, 2018). Thus, extractivist practices are inextricably entangled with European colonialism, the development of the modern world system, and the Enlightenment and scientific revolution (Merchant, 1983). Scholars such as Moore (2015) and Escobar (2016) argue that the economic forces and imaginaries creating the contemporary world system started to become dominant during the longue durée of the 16th century and thereafter became hegemonic among states of all ideologies, permeating the epistemological culture of most governments and international politics. Extraction and anthropocentric appropriation, which are ecologically destructive and aimed at building empires, have even deeper roots, with world systems analysts pointing to a 5,000-year history of imperial capital demolishing environments (Frank and Gills, 1993).

A clear example of anthropocentric appropriation is the long and wide-ranging history of deforestation (Perlin, 2005). However, what differentiates the ancient deforestations and other extractions from the past 500 years of extractivism is the scale, and the greater domination of certain mindsets, by the advancement of modern technology alongside political and military power. These have gradually wiped out prior and co-existing, nurturing, regenerative, and sacredness-based understandings and ontologies of the earth (Merchant, 1983). Yet Merchant (2013) traces the foundation of modernity's relations of the domination of nature to Greek 
and Christian narratives which helped to pave the way for the modern colonialcapitalist era. Similarly, Harvey emphasizes how the idea of the "domination of nature" has strongly influenced both scientific writing and the popular imagination since the Enlightenment era (2014, p. 247). More precisely, the historian Andrew Fitzmaurice (2007), writing on the origins of the concept of terra nullius, provides a lucid account of this conception of the world as it was maintained through the Ancient, Christian, and Enlightenment histories of Europe-at first philosophical and later legal—and which holds the key to the ontological basis for a logic of extractivism.

The ontological basis for the logic of extractivism was first promulgated by the ancient Greeks as "natural law" before being codified by the Romans as the "law of first taker" (or ferae bestiae, the law of wild beasts), and eventually reified as res nullius, or "a thing belonging to no one" under international law in the late 19th century (Fitzmaurice, 2007). The genealogy of the natural law concept is significant on at least two accounts. First, the law asserts that property, and therefore humanity, is established through the exploitation of the potential of things in the physical world. Where the exploited thing in question has no (human) owner, it comes under ownership of the exploiting party (Fitzmaurice, 2007). It is the notion of exploitation in natural law-dependent on assumptions about property and the dominance of humans over "nature"-where the seed of this extractivist ontologic begins to express itself. Second, the interpretation of the ferae bestiae was central to debates in Europe on the justification of colonial dispossession and domination. For example, Francisco de Vitoria, a theologian at the School of Salamanca in the 16th century, used ferae bestiae to argue against Spanish colonial plunder (Fitzmaurice, 2007; de Vitoria, 2010). However, the English inverted the interpretation of this law (e.g. John Locke's Second Treatise of Government, Chapter $\mathrm{V}$ ), reasoning that by not having properly exploited nature - that is, through their labor-the native populations of the Americas (and later Aboriginal Australians) had not established their humanity, and therefore, did not hold just dominion over the lands on which the Europeans first encountered them (Fitzmaurice, 2007). The colonists had only to exploit the nature (and people) of their newfound lands through their labor in order to take ownership of them. Thus, exploitation was first carried out through direct physical violence so as to carve out lands for the new immigrants to "properly" exploit, followed by transformations of these landscapes that more closely resembled those they had left across the Atlantic. Extractivist violence was thus the central tool and mindset in consolidating and legitimizing Western colonial dominance.

This extractivist mindset paved the way for centuries of violence and destruction against indigenous communities and ecosystems. It is no stretch to see that this reinterpretation of natural law via ferae bestiae required additional forms of subjugation, including the racialization of non-Europeans, which was added to the already-operative linear notion of human development as progressing from savage to civilized. This rationale marked a turning point in the modern colonial project and set the stage for a world economy that increasingly and more intensively 
hinged upon an extractivist conception of world-making, as filtered down through the centuries from ancient Greece and Christianity. By the end of the 17 th century, there was a gathering ethos of gaining mastery over nature through technology and the new science of mechanics, which supported a Western worldview of exploitation, subduing prior notions of a "nurturing earth mother" (Merchant, 1983, p. 116). It is notable that this process turned global only within the past 500 years, marking the era of global extractivisms. The onto-logic of exploitations-cum-extractivisms established a prerequisite for the advent of the modern world-system and appears pervasive in all forms that the system now takes, having intensified even more in the past century. We find an increasing number of scholars utilizing extraction and extractivism to understand new forms of violent regimes that have emerged only in the 20th and 21st century, ranging from neoliberal to progressive governments' macro-developmental projects (e.g. Gudynas, 2015; Svampa, 2019).

\section{Futures for Resistance, extrACTIVISMS, and Violence}

Extractivist activity and its enablers are increasingly being contested on the ground, particularly by those whose ontological understandings of the world are, or have become, antithetical to the extractivist onto-logic, and who face extractivist violence and threat of extinction by extractions. Understanding how these resistances play out and their effects on extractivist practices locally, regionally, and globally, is a key task for researchers and extrACTIVISTS (Willow, 2018) wishing to analyze, critique, or intervene. Wapner (in this volume) argues that extrACTIVISM is a new phenomenon in the line of environmental justice struggles starting in North America. Willow (2018) offers examples of how extrACTIVISM takes place in particular places, where populations - such as the indigenous people resisting oil pipelines in North America - are fundamentally resisting the increased extraction at these sites while simultaneously being opposed to the logic, global impacts, and connotations of these extractivist expansions. Kröger (2013; 2020a) analyzes how this kind of resistance to extractivism has been able to succeed in discontinuing or slowing down the expansion of extractivisms of global industrial forestry and mining in Brazil and India. He emphasizes that there are five key resistance strategies that resistance to global extractivisms should use, as well as some strategies that they should avoid, if, for instance, the goal of the resistance is not simply to allow for a modified expansion of extractions or receive compensation, but to block, discontinue, and reverse investment projects that are destructive for the planet and the localities. These key strategies support the fostering of contentious agency and the establishment of resistance actors that vary in shape (including non-governmental organizationss, networks, difference-scale actors, social movements, indigenous groups, trade unions, environmentalists, different classes, and mixes of these) and share the quality of resisting primarily via physically disruptive and innovative protest tactics such as roadblocks, blocking entrances to would-be extraction sites, bodily resistance, cutting down eucalyptus plantations, or other tactics which are not violent toward humans. They also include "non-violent" 
strategies such as the use of lawsuits and even intervention by activist government agencies. Key to these resistances is the retention of alternative physical, social, and symbolic territories and territorialities. They rely on tight and distinct place-based affinities to places rendered as non-commensurable and non-commodifiablepractices that challenge the onto-epistemic logic of extractivism. Besides protesting, the other necessary strategy that Kröger (2020a) identifies is the avoidance of making private deals directly with companies in private politics, such as stakeholder dialogues, which do not seem to work for the benefit of extrACTIVISTS. There are other strategies and factors that need to be considered when assessing the role of resistance to extractivisms in different sectors, polities, and contexts, in order to understand and analyze the complexities and dynamics in global extractivist politics: Kröger (2020d) offers methodological guidelines on how to analyze these factors through multi-sited political ethnography and Qualitative Comparative Analysis. More detailed, systematic, globally spanning analyses across and within different global extractivisms and their resistance are needed.

While identifying the manifestations of violence produced through extractivist activities is paramount, it is not always an easy task. For example, when the violence that originates in extractive practices plays out in ways far removed from their locus, as in the case of digital extractivisms, as Chagnon et al. show in their chapter in this volume. Nonetheless, the identification of how violence plays out is crucial for devising activist strategies and organizing research in ways that augment more effective resistance, anticipatory actions, or media strategies. Taken from an ontological perspective, the presence of extractivist logics is more ubiquitous than meets the eye, but for this reason allows for the possibility of more effective diagnosis and action. A future research agenda, for which this volume boasts a collection of key examples, should strive to communicate and collaborate with extrACTIVISMS as they unfold and emerge both in established and new resource frontiers.

\section{Conclusion}

This chapter has outlined how extraction and extractivism have been used as concepts and how they can be used in reference to violence. We provided an etymological analysis of the Latin roots of the key concepts and distinguished different historical epochs, timelines, and roots of global extractivisms as an ontological feature of the modern world-ecology, as nested in a longer succession of world systems. Although these dynamics began to gain traction about 500 years ago, ontologically extractivist mindsets and practices already existed-depleting, destroying, and deforesting lived environments for thousands of years before the modern world-system-as is visible in the building of empires and ancient civilizations. However, in our age, the extractivist thrust has become ever more widespread, violent, and global in scale and pace. The line between tangible and intangible realms of extraction has become blurred as financial speculation and markets that are digitized and run by algorithms have spread. There are precursors to this current state-of-affairs in bio-piracy and intellectual theft, 
as well as the longer necessity of mapping and codifying lands, resources, and the possibilities of exploitation and extraction in capital's commensurability project (see Moore, 2015). These expansions have direct and indirect links to extractions based on appropriative accumulation, both in human and other-than-human natures.

The different arenas of extractivist logic need to be further explored by providing broader, overarching assessments that seek to unveil the complex webs of extractivisms in this era. In this endeavor, we suggest an inclusive definition of extractivism as $a$ particular way of thinking and the properties and practices organized towards the goal of maximizing benefit through extraction, which brings in its wake violence and destruction.

\section{Notes}

1 “extract." Merriam-Webster.com. 2020. https://www.merriam-webster.com

2 “extract, v." Oxford English Dictionary Online. 2020. Oxford University Press. https:// www-oed-com.libproxy.helsinki.fi/view/Entry/67080?rskey=BaUkPe\&result=3

3 “-ismo." Diccionario de la lengua española. 2020. Real Academia Español. https://dle.rae.es

4 “-ismo." Dizionario delle Scienze Fisiche. 1996. Treccani. http://www.treccani.it/enciclop edia/ismo_ \%28Dizionario-delle-Scienze-Fisiche \%29/

\section{References}

Acosta, A. (2013) 'Extractivism and neoextractivism: Two sides of the same curse', Beyond development: alternative visions from Latin America, 1, pp. 61-86.

Acosta, A. (2015) 'Después del saqueo: Caminos hacia el posextractivismo, Perspectivas, Análisis y Comentarios Políticos', América Latina, 1, pp. 12-17. Available at: https://mx. boell.org/sites/default/files/perspectivas_1_version_online.pdf.

Alonso-Fradejas, A. (2018) 'The rise of agro-extractive capitalism: Insights from Guatemala in the early 21st century', $\mathrm{PhD}$ Thesis, Erasmus University Rotterdam, International Institute of Social Studies at The Hague, Netherlands.

Arboleda, M. (2020) Planetary Mine: Territories of Extraction under Late Capitalism. London: Verso Books.

Bebbington, A. and Bury, J. (2013) Subterranean Struggles: New Dynamics of Mining, Oil, and Gas in Latin America. Austin, TX: University of Texas Press.

Brand, U., Dietz, K., and Lang, M. (2016) 'Neo-Extractivism in Latin America. One Side of a New Phase of Global Capitalist Dynamics', Ciencia Política, 11 (21), pp. 125-159.

Couldry, N. and Mejias, U. (2019) The Costs Of Connection: How Data Is Colonizing Human Life And Appropriating It For Capitalism. Stanford, CA: Stanford University Press.

De la Cadena, M. and Blaser, B. (2018) A World of Many Worlds. Durham, NC: Duke University Press.

De Vitoria, F. (2010) Political writings. A. Pagden and J. Lawrance (eds). Cambridge: Cambridge University Press.

Dunlap, A. and Jakobsen, J. (2020) The Violent Technologies of Extraction: Political Ecology, Critical Agrarian Studies and the Capitalist Worldeater. London: Palgrave MacMillan.

Ehrnström-Fuentes, M. and Kröger, M. (2018) 'Birthing extractivism: The role of the state in forestry politics and development in Uruguay', Journal of Rural Studies, 57, pp. 197-208.

Escobar, A. (1995) Encountering development: The making and unmaking of the Third World. Princeton, NJ: Princeton University Press. 
Escobar, A. (2016) 'Thinking-feeling with the Earth: Territorial Struggles and the Ontological Dimension of the Epistemologies of the South', AIBR. Revista de Antropología Iberoamericana, 11 (1), pp. 11-32.

Fitzmaurice, A. (2007) 'The genealogy of terra nullius', Australian Historical Studies, 38 (129), pp. 1-15.

Frank, A. and Gills, B. (eds.) (1993) The World System: Five Hundred Years or Five Thousand? London: Routledge.

Gago, V. and Mezzadra, S. (2017) 'A critique of the extractive operations of capital: Toward an expanded concept of extractivism', Rethinking Marxism, 29 (4), pp. 574-591.

Gudynas, E. (2015) Extractivismos: Ecología, economía y política de un modo de entender el desarrollo y la naturaleza. 1st ed. Cochabamba: Centro de Documentación e Información Bolivia.

Gudynas, E. (2018) 'Extractivisms: Tendencies and Consequences'. In Munck, R. and Wise, R.D. (eds.) Reframing Latin American Development. New York, NY: Routledge.

Harvey, D. (2014) Seventeen Contradictions and the End of Capitalism. London: Profile Books.

Jalbert, K., Willow, A., Casagrande, D., and Paladino, S. (eds.) (2017) ExtrACTION: Impacts, Engagements, and Alternative Futures. London: Routledge.

Kröger, M. (2013) Contentious Agency and Natural Resource Politics. London: Routledge.

Kröger, M. (2015) 'Spatial Causalities in Resource Rushes: Notes from the Finnish Mining Boom', Journal of Agrarian Change, 16 (4), pp. 543-570.

Kröger, M. (2016) 'The political economy of 'flex trees': a preliminary analysis', The Journal of Peasant Studies, 43 (4), pp. 886-909.

Kröger, M. (2020a) Iron Will: Global Extractivism and Mining Resistance in Brazil and India. Ann Arbor, MI: University of Michigan Press.

Kröger, M. (2020b) Politics of Extraction: Theories and New Concepts for Critical Analysis. Oxford Bibliographies Online in International Relations.

Kröger, M. (2020c) Natural Resources, Energy Politics, and Environmental Consequences. Oxford Bibliographies Online in International Relations.

Kröger, M. (2020d) Studying Complex Interactions and Outcomes Through Qualitative Comparative Analysis: A Practical Guide to Comparative Case Studies and Ethnographic Data Analysis. London: Routledge.

Kröger, M. and Ehrnström-Fuentes, M. (2020) 'Forestry Extractivism: Uruguay'. In McKay, B.M., Alonso-Fradejas, A., and Ezquerro-Cañete, A. (eds.) Agrarian Extractivism in Latin America. London: Routledge.

Kröger, M. and Nygren, A. (2020) 'Shifting Frontier Dynamics in Latin America', Journal of Agrarian Change. 20 (3), pp. 364-386.

Locke, J. (2010) Second Treatise of Government. Project Gutenberg. Available at: https:// www.gutenberg.org/files/7370/7370-h/7370-h.htm.

Machado Araóz, H. (2013) 'Crisis ecológica, conflictos socioambientales y orden neocolonial: Las paradojas de NuestrAmérica en las fronteras del extractivismo', REBELA-Revista Brasileira de Estudos Latino-Americanos, 3 (2), pp. 118-155.

McKay, B.M. (2017) 'Agrarian Extractivism in Bolivia', World Development, 97, pp. 199-211.

McNeish, J.A. (2018) 'Resource Extraction and Conflict in Latin America'. Colombia Internacional (93), pp. 3-16. Available at: https://dx.doi.org/10.7440/colombiaint93.2018.01.

Merchant, C. (1983) 'Mining the Earth's Womb'. In Rothschild, J. (ed.) Machina Ex Dea: Feminist Perspectives on Technology. Oxford: Pergamon Press.

Merchant, C. (2013) Reinventing Eden: The Fate of Nature in Western Culture. New York, NY: Routledge.

Mezzadra, S. and Neilson B. (2017) 'On the multiple frontiers of extraction: Excavating contemporary capitalism', Cultural Studies, 31(2-3), pp. 185-204. 
Mintz, S.W. (1986) Sweetness and power: The place of sugar in modern history. New York, NY: Penguin Books.

Moore, J.W. (2015) Capitalism in the Web of Life: Ecology and the Accumulation of Capital. London: Verso Books.

Peluso, N.L. and Watts, M. (eds.) (2001) Violent Environments. Ithaca, NY: Cornell University Press.

Perlin, J. (2005) A Forest Journey: The Story of Wood and Civilization. New York, NY: The Countryman Press.

Sadowski, J. (2019) 'When data is capital: Datafication, accumulation, and extraction', Big Data \& Society, 6 (1), pp. 1-12.

Scott, J.C., (2017) Against the Grain: A Deep History of the Earliest States. New Haven, CT: Yale University Press.

Shapiro, J. (2018) 'As China Goes, So Goes the Planet: The Environmental Implications of the Rise of China'. In Kütting, G. and Herman, K. (eds.) Global Environmental Politics. Routledge, London.

Svampa, M. (2019) Neo-extractivism in Latin America Socio-environmental Conflicts, the Territorial Turn, and New Political Narratives. Cambridge and New York, NY: Cambridge University Press.

Szelényi, I. and Mihályi, P. (2020) Varieties of post-communist capitalism: A comparative analysis of Russia, Central Europe and China, Studies in critical social sciences. Leiden, Boston, MA: Brill.

Taylor, M. (2015) The Political Ecology of Climate Change Adaptation: Livelihoods, Agrarian Change and the Conflicts of Development. London: Routledge.

Teràn Mantovani, E. (2016) 'Las Nuevas Fronteras de Las Commodities En Venezuela: Extractivismo, Crisis Histórica y Disputas Territoriales', Ciencia Política, 11 (21), pp. 251-285.

Thatcher, J., O'Sullivan, D., and Mahmoudi, D. (2016) 'Data colonialism through accumulation by dispossession: New metaphors for daily data', Environment and Planning D: Society and Space, 34 (6), pp. 990-1006.

Wallerstein, I. (1974) The Modern World-System I. New York: Academic Press.

Willow, A.J. (2018) Understanding ExtrACTIVISM: Culture and Power in Nature Resource Disputes. London: Routledge.

Ye, J., van der Ploeg, J.D., Schneider, S., and Shanin, T., (2020) 'The incursions of extractivism: Moving from dispersed places to global capitalism', The Journal of Peasant Studies, 47 (1), pp. 155-183. 